\title{
HUBUNGAN BRAND EXPERIENCE, BRAND IMAGE, BRAND SATISFACTION, DAN BRAND LOYALTY DALAM PESPEKTIF FOUR- STAGE LOYALTY MODEL (STUDI TERHADAP MAHASISWA PENGGUNA SMARTPHONE DI TARAKAN)
}

\author{
Rahmat $^{1}$, Marso $^{2 *}$ \\ 1,2 Departemen Manajemen, Sekolah Tinggi Ilmu Ekonomi Bulungan Tarakan \\ Jl. Gunung Amal RT. 14, Kampung Enam, Tarakan, Kalimantan Timur 77123 \\ *Penulis Koresponden: marso_ok@yahoo.com
}

\begin{abstract}
Abstrak: Penelitian ini dilakukan untuk menguji pengaruh langsung brand experience terhadap brand image, brand satisfaction, dan brand loyalty. Populasi penelitian ini adalah mahasiswa di Tarakan. Sampel penelitian ini terdiri dari 128 responden yang ditarik dengan metode nonprobability sampling. Software yang digunakan untuk menguji validitas dan reliabilitas instrumen serta menguji hipotesis penelitian ini adalah SmartPLS 3.0 Professional. Hasil penelitian ini menunjukkan bahwa brand experience berpengaruh langsung secara positif dan signifikan terhadap brand image, pengaruh langsung brand experience terhadap brand satisfaction tidak signifikan, pengaruh langsung brand experience terhadap brand loyalty tidak signifikan, brand image berpengaruh langsung secara positif dan signifikan terhadap brand satisfaction, pengaruh langsung brand image terhadap brand loyalty tidak signifikan, dan brand satisfaction berpengaruh langsung secara positif dan signifikan terhadap Brandloyalty. Selain membahas hasil pengujian pengaruh langsung, peran brand image dan brand satisfaction sebagai variabel mediator juga dibahas dalam penelitian ini. Secara teoritis, hasil penelitian ini berkontribusi dalam pengembangan anteseden loyalitas pelanggan; sedangkan secara pragmatis, temuan penelitian ini dapat bermanfaat sebagai bahan dalam merumuskan strategi untuk meningkatkan loyalitas pengguna Smartphone.
\end{abstract}

Kata kunci: Brand experience; brand image; brand satisfaction; brand loyalty.

\begin{abstract}
This research was conducted to examine the direct effect of brand experience on brand image, brand satisfaction, and brand loyalty. The study population was students in Tarakan. The sample of this study consisted of 128 respondents who were drawn by the nonprobability sampling method. Software used to test the validity and reliability of the instrument and to test the hypothesis of this study was SmartPLS 3.0 Professional. The results of this study indicate that brand experience has a direct positive and significant effect on brand image, the direct effect of brand experience on brand satisfaction is not significant, the direct effect of brand experience on brand loyalty is not significant, brand image has a direct positive and significant effect on brand satisfaction, influence direct brand image on brand loyalty is not significant, and brand satisfaction has a positive and significant direct effect on Brandloyalty. In addition to discussing the results of direct influence testing, the role of brand image and brand satisfaction as mediator variables is also discussed in this study. Theoretically, the results of this study contribute to the development of customer loyalty antecedents; while pragmatically, the findings of this study can be useful as material in formulating strategies to increase the loyalty of Smartphone users
\end{abstract}

Keywords: Brand experience; brand image; brand satisfaction; brand loyalty;

\section{PENDAHULUAN}

Perkembangan jumlah penduduk yang didukung daya beli yang terus meningkat telah mendorong peningkatan jumlah permintaan terhadap perangkat teknologi informasi dan komunikasi. Kehadiran ponsel pintar atausmartphoneterbaru di tengah-tengah kehidupan mengubah cara atau gaya berkomunikasi manusia. Istilah smartphone mengacu pada teknologi komunikasi atau handphone yang dilengkapi dengan berbagai macam fitur canggih yang dapat dipilih sesuai dengan keinginan pengguna smartphone. Jika duluhandphonehanyadipakai untuk menelepon dan mengirim pesan singkat atau SMS (short message services), kini handphone sudah bersifat multifungsi
(Prasetya, 2019). Kemampuan smartphone untuk memenuhi keinginan pengguna telah mendorong pasar smartphone Indonesia tumbuh dua digit pada tahun 2018, yakni sebesar 17,1\% dibanding tahun 2017 (Pertiwi, W.K., 2018). Menurut Prasetya (2019), jumlah merek smartphone yang beredar di Indonesia lebih dari 60 merek. Lima vendor penguasa smartphone di Indonesia tidak mengalami perubahan dibandingkan kuartal sebelumnya, yaitu Samsung masih bertahan di posisi puncak dengan market share 25,4\%, diikuti Xiaomi 20,5\%, Oppo 19,5\%, Vivo 15,9\%, dan Advan 4,1\% (Rayana, 2019). Dengan demikian, lebih dari 50 merek smartpone lainnya harus bersaing ketat untuk mendapat bagian dari $14,6 \%$ pangsa pasar yang tersisa. Kemampuan 
perusahaan untuk memenangkan pasar dalam industri yang sangat kompetitif tidak hanya ditentukan oleh kemampuan menarik pelanggan baru, tetapi harus mampu mempertahankan pelanggan baru yang telah diperoleh dengan biaya tinggi tersebut agar tetap menggunakan produk-produk perusahaan di masa yang akan datang.

Keputusan konsumen untuk membeli dan menggunakan produk dari perusahaan yang sama pasca pembelian dikenal dengan istilah loyalitas (Oliver, 1997; Lovelock \& Wirtz, 2011). Loyalitas merupakan aspek kritis bagi perusahaan karena lebih menguntungkan dan lebih murah daripada menarik pelanggan baru (Petrick dan Sirakaya, 2004) dan terbukti memiliki hubungan dengan profitabilitas (Hallowell, 1996). Loyalitas pelanggan adalah komitmen untuk membeli kembali atau berlangganan produk atau jasa yang disukai secara konsisten di masa depan, meskipun pengaruh situasional dan upaya pemasaran memiliki potensi untuk menyebabkan perilaku beralih (Oliver, 1997:392). Pelanggan yang loyal akan bersedia untuk terus berlangganan pada suatu perusahaan dalam jangka panjang, secara eksklusif, dan merekomendasikan produk perusahaan kepada orang lain (Lovelock dan Wirtz, 2011). Dengan demikian, loyalitas terhadap merek smartphone tertentu memotivasi pelanggan untuk melakukan pembelian ulang, menyatakan hal positif tentang merek smartphone yang telah digunakan, dan merekomendasikan merek smartphone kepada orang lain.

Berbagai penelitian terdahulu mengungkapkan bahwa loyalitas pengguna smartphone merupakan konsekuensi dari kepuasan merek (Sahin et al., 2011; Kassim et al., 2014; Mehmood \& Shafiq, 2015; Pourdehghan, 2015; Goh, 2016, Dunuwille \& Pathmini, 2016; Fazal \& Kanwal, 2017; Moreira et al., 2017), brand experience (Sahin et al., 2011; Nagar \& Bendary, 2017), dan brand image (Durrani et al., 2015; Mehmood \& Shafiq, 2015). Selain berfungsi sebagai anteseden loyalitas, penelitian terdahulu juga mengungkapkan bahwa kepuasan merek merupakan konsekuensi brand experience (Sahin et al., 2011; Moreira et al., 2017), dan brand image (Dunuwille \& Pathmini, 2016). Hasil temuan penelitian terdahulu ini menyiratkan bahwa kepuasan merek dapat berperan sebagai variabel yang memediasi pengaruh brand experience dan brand image terhadap brand loyalty. Namun, belum ada studi empiris yang menguji hubungan antar variabel yang menguji hubungan antara loyalitas merek dengan kepuasan merek, brand experience, dan brand image, serta hubungan kepuasan merek dengan brand expereince dan brand image dalam satu model sehingga peran kepuasan merek dalam memediasi pengaruh brand experience dan brand image terhadap brand loyalty belum terungkap. Untuk itu, penelitian ini mengkombinasikan beberapa model empiris terdahulu untuk menguji hubungan antar variabel "brand experience $\rightarrow$ brand image $\rightarrow$ brand satisfaction $\rightarrow$ brand loyalty" dalam perspektif Four-Stage Loyalty Model (Oliver, 1997) melalui model persamaan struktural.

Model persamaan struktural yang dikembangkan dalam penelitian ini bertujuan untuk menguji pengaruh langsung brand experience terhadap brand image, pengaruh langsung dan pengaruh tidak langsung brand experience terhadap brand satisfaction, pengaruh langsung dan pengaruh tidak langsung brand experience terhadap brand loyalty, pengaruh langsung brand image terhadap brand satisfaction, pengaruh langsung dan pengaruh tidak langsung terhadap brand loyalty, dan pengaruh langsungbrand satisfaction terhadap brand loyalty. Data yang digunakan untuk menguji model yang diajukan dalam penelitian ini diperoleh melalui kuesioner yang didistribusikan kepada mahasiswa di Tarakan.

\section{LANDASAN TEORI DAN PENGEMBANGAN HIPOTESIS}

\section{Four-Stage Loyalty Model}

Untuk mempelajari perilaku konsumen pasca keputusan pembelian, Oliver (1997) mengembangkan teori loyalitas berdasarkan attribute-base models of attitude yang gagas Fisbhein dan Ajzen (1975). Teori loyalitas yang dilkembangkan Oliver (1997) diberi label Four-Stage-Loyalty Model. Pola Four-StageLoyalty Modeladalah cognitive $\rightarrow$ affective $\rightarrow$ conative $\rightarrow$ action. Komponen-komponen sikap yang mencakup kognitif (pengetahuan), afektif (aspek emosional atau perasaaan), dan konatif (niat atau komitmen) pada dasarnya merupakan dimensi loyalitas yang tidak konsonan. Komponen-komponen tersebut akan menjadi konsonan melalui arti kognitif, cara afektif, arti konatif, dan cara perilaku secara berurutan. Menurut Oliver (1997), tiga fase attitudinal loyalty (kognitif, afektif, dan konatif) melibatkan "sustainners" untuk memperkuat tingkat loyalitas (misalnya, nilai berdasarkan aspek fungsional untuk cognition, kepuasan untuk affect, dan komitmen untuk conation). Komitmen atau niat loyalitas dianggap sama dengan action loyalty sebagai fase keempat dari FourStage-Loyalty Model. Untuk itu, mayoritas penelitian empiris hanya menguji Four-Stage-Loyalty Model sampai pada fase ketiga karena action loyalty dianggap sama dengan aspek konatif, yaitu niat atau komitmen (Oliver, 1997). 


\section{Brand Experience}

Praktisi pemasaran menyadari bahwa memahami pengalaman pelanggan terhadap merek sangat penting untuk mengembangkan strategi pemasaran barang dan jasa (Pine \& Gilmore 1998; Schmitt 1999, 2003; Brakus et al., 2009). Mengelola pengalaman pelanggan pada umumnya dianggap menciptakan keunggulan kompetitif bagi perusahaan, serta berdampak positif pada merek (Ismail, 2010). Pengalaman merek dikonsep tualisasikan sebagai sensasi, perasaan, kognisi, dan respons perilaku yang ditimbulkan oleh rangsangan terkait merek yang merupakan bagian dari desain dan identitas, pengemasan, komunikasi, dan lingkungan merek (Brakus et al., 2009). Seiring dengan waktu, pengalaman merek yang mampu bertahan lama tersimpan dalam memori konsumen dapat mempengaruhi kepuasan dan loyalitas konsumen (Oliver 1997; Reicheld 1996). Beberapa penelitian terdahulu mengungkapkan bahwa brand experience berpengaruh langsung secara positif dan signifikan terhadap brand satisfaction (Sahin et al., 2011; Moreira et al., 2017), dan brand loyalty (Sahin et al., 2011; Nagar \& Bendary, 2017)

$H_{l}$ : Brand experience berpengaruh langsung secara positif dan signifikan terhadap brand image pengguna smartphone di Tarakan

$H_{2 a}$ : Brand experience berpengaruh langsung secara positif dan signifikan terhadap brand satisfaction pengguna smartphone di Tarakan

$H_{2 b}$ : Pengaruh brand experience terhadap terhadap brand satisfaction pengguna smartphone di Tarakan dimediasi oleh brand image.

$H_{3}$ : Brand experience berpengaruh langsung secara positif dan signifikan terhadap brand loyalty pengguna smartphone di Tarakan

\section{Brand Image}

Dalam pasar yang kompetitif dan sadar merek, membangun brand image pelanggan ponsel merupakan tugas yang menantang (Dunuwille \& Pathmini, 2016). Brand image adalah persepsi tentang suatu merek sebagaimana tercermin oleh asosiasi merek yang ada dalam ingatan konsumen (Keller, 1993). Hasil penelitian terdahulu mengungkapkan bahwa Brand Image berpengaruh lansung secara positif dan signifikan terhadap brand satisfaction (Dunuwille \& Pathmini, 2016), dan brand loyalty (Durrani et al., 2015; Mehmood \& Shafiq, 2015)

$\mathrm{H}_{4}$ : Brand image berpengaruh langsung secara positif dan signifikan terhadap brand satisfaction pengguna smartphone di Tarakan.

$H_{5}$ : Brand image berpengaruh langsung secara positif dan signifikan terhadap brand loyalty pengguna smartphone di Tarakan.
$H_{5 a}$ : Pengaruh brand image terhadap brand loyalty pengguna smartphone di Tarakan dimediasi oleh brand satisfaction.

\section{Brand Satisfaction}

Kepuasan adalah salah satu konsep inti pemasaran (Kolter \& Keller, 2016: 31), salah satu konsep yang terasuk dalam komponen loyalitas afektif (Oliver, 1997, p. 394), dan telah banyak dipelajari dalam pemasaran selama beberapa dekade terakhir ini (Tsiotsou, 2005). Kepuasan didefinisikan sebagai perasaan senang atau kecewa individu yang berasal dari perbandingan antara persepsi terhadap kinerja (atau hasil) dengan harapan-harapannya terhadap produk (Kotler \& Keller, 2016:153). Berbagai penelitian terdahulu mengungkapkan bahwa loyalitas pengguna smartphone merupakan konsekuensi dari kepuasan merek (Sahin et al., 2011; Kassim et al., 2014; Mehmood \& Shafiq, 2015; Pourdehghan, 2015; Goh, 2016, Dunuwille \& Pathmini, 2016; Fazal \& Kanwal, 2017; Moreira et al., 2017). Berdasarkan temuan berbagai penelitian terdahulu tersebut, maka dapat dirumuskan hipotesis berikut ini:

$H_{6}$ : Brand satisfaction berpengaruh langsung secara positif dan signifikan terhadap brand loyalty pengguna smartphone di Tarakan

\section{METODE PENELITIAN}

\section{Populasi dan Sampel}

Populasi penelitian ini adalah mahasiswa pengguna smartphone di Tarakan, Indonesia. Sampel penelitian ditarik dengan metode non probabilitas, yaitu accidental sampling. Untuk memperoleh jumlah sampel yang diinginkan, kuesioner penelitian didistribusikan kepada mahasiswa di lima perguruan tinggi di Tarakan, Indonesia pada Mei dan Juni 2019. Jumlah kuesioner yang didistribusikan adalah 150 set kuesioner. Jumlah kuesioner yang dikembalikan adalah 136 atau 74,8\% dari 150 kuesioner yang didistribusikan. Dari 136 yang dikembalikan, hanya 128 atau 94,1\% yang dapat digunakan sebagai bahan analisis. Mayoritas responden penelitian ini adalah perempuan (54\%), berusia 20 - 25 tahun (54\%), menggunakan smartphone yang telah dibeli lebih dari dua tahun (52\%), telah membeli smartphone dengan merek yang sama lebih dari tiga kali (45\%), mengetahui merek smartphone dari iklan di Televisi (47\%).

\section{Variabel dan Pengukuran}

Variabel penelitian ini ada empat, yaitu brand experience, brand image, brand satisfaction, dan brand loyalty. Indikator-indikator yang digunakan 
untuk mengukur variabel penelitian ini (lihat Tabel 1), diadopsi dari indikator-indikator yang dikembangkan oleh Ahmed \& Moosavi (2013). Alternatif jawaban untuk setiap indikator diukur dengan skala Likert, mulai dari 1 (sangat tidak setuju) sampai dengan 5 (sangat setuju).

\section{Analisis Data}

Pengujian model pengukuran dan hipotesis yang diajukan dalam penelitian ini dianalisis menggunakan PLS-SEM dan diproses dengan SmartPLS 3.0 Profesional (Ringle et al., 2015). PLS-SEM memungkinkan peneliti untuk mengonseptualisasikan higherorder factors dengan menggunakan variabel manifes secara berulang (Chin et al., 2003; Tenenhaus et al., 2005; Kleijnen et al., 2007). Model struktural yang dikembangkan dengan PLS-SEM juga tidak perlu dievaluasi dengan $G o F$, karena hasil dari model pengukuran dan model struktural sudah dianggap cukup untuk menjelaskan ketepatan model yang dikembangkan (Hair et al., 2014:186).

\section{HASIL PENELITIAN}

\section{Model Pengukuran}

Konstruk yang digunakan dalam model penelitian yang dikembangkan harus dihasilkan dari instrumen atau alat pengukuran yang valid dan reliabel. Untuk itu, validitas instrumen dapat diukur dengan validitas konvergen. Hasil uji validitas membuktikan bahwa semua variabel penelitian memiliki loading factor lebih besar dari 0,50, AVE lebih besar dari 0,50,

Tabel 1. Hasil Evaluasi Model Pengukuran dan Second Order Reflective Factors

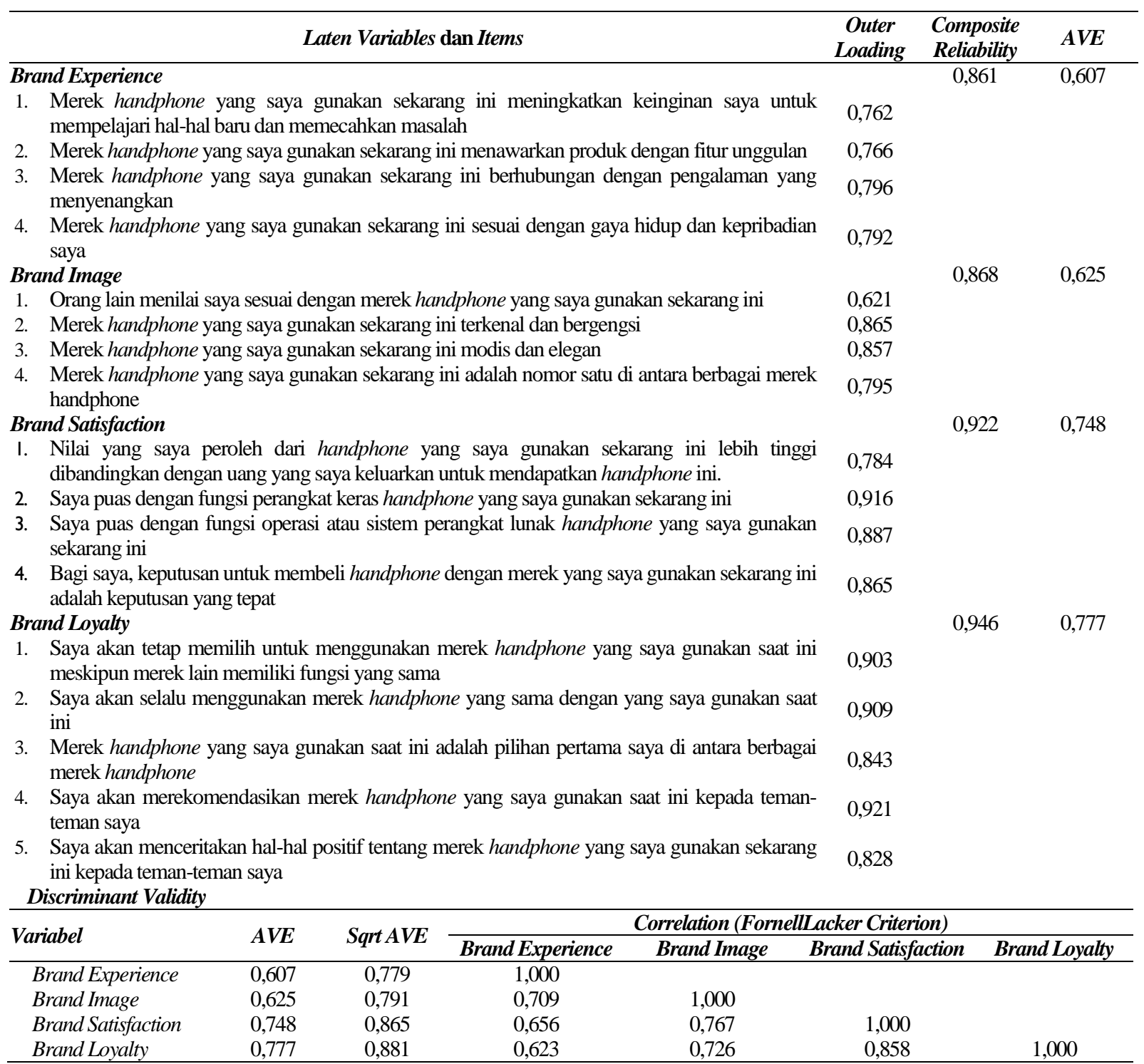

Sumber: SmartPLS Output

Keterangan: AVE:Average Variance Construct 
serta reliabilitas komposit lebih dari 0,70. Berdasarkan FornellLarcker Criterion, nilai validitas diskriminan juga terpenuhi karena nilai akar kuadrat dari $A V E$ untuk setiap variabel lebih tinggi daripada nilai korelasi antar masing-masing variabel. Hasil model pengukuran dapat dilihat pada Tabel 1.

\section{Model Struktural}

Hasil evaluasi gejala collinearity pada model struktural penelitian ini (Tabel 2) menunjukkan bahwa nilai VIF antar konstruk prediktor lebih tinggi dari 0,20 dan lebih rendah dari 5,00. Dengan demikian, tidak perlu untuk menghilangkan konstruk atau menggabungkan prediktor dalam satu konstruk (Hair et al., 2014:170), dan penilaian model struktural untuk mengetahui signifikansi koefisien jalur, kemampuan prediksi $\left(R^{2}\right)$, serta predictive relevance $\left(Q^{2}\right)$ dapat dilanjutkan.

Tabel 2. Collinearity Statistic (VIF)

\begin{tabular}{lccc}
\hline & $\begin{array}{c}\text { Brand } \\
\text { Image }\end{array}$ & $\begin{array}{c}\text { Brand } \\
\text { Satisfaction }\end{array}$ & $\begin{array}{c}\text { Brand } \\
\text { Loyalty }\end{array}$ \\
\hline Brand Experience & 1,000 & 2,009 & 2,143 \\
Brand Image & - & 2,009 & 2,959 \\
Brand Satisfaction & - & - & 2,588 \\
\hline
\end{tabular}

Sumber: SmartPLS Output

Tabel 3. Nilai $R^{2}$ dan $Q^{2}$ Variabel Endogen

\begin{tabular}{lcc}
\hline & $\boldsymbol{R}^{\mathbf{2}}$ & $\mathbf{Q}^{\mathbf{2}}$ \\
\hline Brand Image & 0,502 & 0,287 \\
Brand Satisfaction & 0,614 & 0,419 \\
Brand Loyalty & 0,749 & 0,538 \\
\hline
\end{tabular}

Sumber: SmartPLS Output

Gambar 1 dan Tabel 4 menunjukkan semua jalur yang dikembangkan dalam model penelitian ini memiliki koefisien yang bertanda positif. Jalur langsung brand experience ke brand image memilili koefisien sebesar $\beta=0,709 ; \quad T=12,027 ; \quad p=0.000$, brand experience ke brand satisfaction dengan koefisien sebesar $\beta=0,227 ; T=1,893 ; p=0,059$, brand experience ke brand loyalty sebesar $\beta=0,054$; $T=0,769 ; p=0.443$, brand image ke brand satisfaction sebesar $\beta=0,606 ; T=5,961 ; p=0.000$, brand imageke brand loyalty sebesar $\beta=0,140 ; T=1,354 ; p=0.000$, dan brand satisfactionke brand loyalty sebesar $\beta=0,715 ; \quad T=9,406 ; \quad p=0.000$. Selanjutnya, nilai $R^{2}$ untuk setiap variabel endogen dapat dikategorikan tinggi karena lebih besar dari 0.20 (Hair et al., 2014:175) dan evaluasi berdasarkan nilai $Q^{2}$ juga menunjukkan bahwa konstruk eksogen memiliki predictive relevance terhadap konstruk endogen karena lebih besar dari 0 .

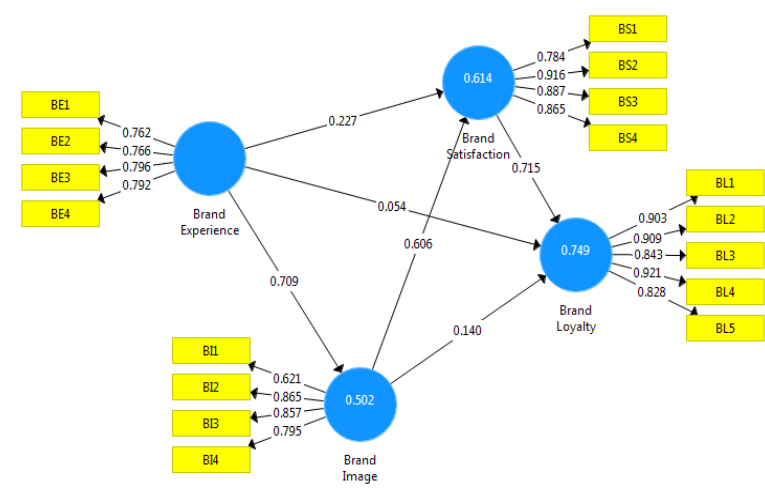

Gambar 1. Model Struktural Sumber: Output SmartPLS

Pengujian peran mediasi perceived quality dan kepuasan dalam model dapat dilanjutkan jika pengaruh tidak langsung brand experience terhadap brand satisfaction, dan pengaruh tidak langsung brand imageterhadap brand loyalty memiliki pengaruh yang signifikan. Dalam hal ini, nilai $V A F$ (the variance accounted for) akan digunakan untuk menentukan skala efek tidak langsung terkait dengan efek totalnya. Nilai $V A F$ diperoleh dengan cara

Table 4. Hasil Pengukuran Direct, Indirect, dan Total Effect

\begin{tabular}{|c|c|c|c|c|c|c|c|c|c|c|}
\hline \multirow{2}{*}{ Jalur } & \multicolumn{3}{|c|}{ Direct Effect } & \multicolumn{3}{|c|}{ Indirect Effect } & \multicolumn{3}{|c|}{ Total Effect } & \multirow{2}{*}{$V A F$} \\
\hline & $\beta$ & $T$ & $P$ & $\beta$ & $T$ & $P$ & $\beta$ & $T$ & $P$ & \\
\hline $\begin{array}{l}\text { Brand Experience } \rightarrow \text { Brand } \\
\text { Image }\end{array}$ & 0,709 & 12,027 & 0.000 & - & - & - & 0,709 & 12,027 & 0.000 & - \\
\hline $\begin{array}{l}\text { Brand Experience } \rightarrow \text { Brand } \\
\text { Satisfaction }\end{array}$ & 0,227 & 1,893 & 0.059 & 0,429 & 6,564 & 0.000 & 6,656 & 8,179 & 0.000 & $34,6 \%$ \\
\hline $\begin{array}{l}\text { Brand Experience } \rightarrow \text { Brand } \\
\text { Loyalty }\end{array}$ & 0,054 & 0,769 & 0,443 & 0,568 & 7,125 & 0,000 & 0,623 & 8,349 & 0,000 & - \\
\hline $\begin{array}{l}\text { Brand Image } \rightarrow \text { Brand } \\
\text { Satisfaction }\end{array}$ & 0,606 & 5,961 & 0,000 & - & - & - & 0,606 & 5,961 & 0,000 & - \\
\hline Brand Image $\rightarrow$ Brand Loyalty & 0,140 & 1,354 & 0,176 & 0,433 & 4,920 & 0,000 & 0,573 & 5,455 & 0,000 & $24,4 \%$ \\
\hline $\begin{array}{l}\text { Brand Satisfaction } \rightarrow \text { Brand } \\
\text { Loyalty }\end{array}$ & 0,715 & 9,406 & 0.000 & - & - & - & 0,411 & 3,704 & 0.000 & - \\
\hline
\end{tabular}

Sumber: SmartPLS Output

Keterangan: $\beta=$ koefisien jalur; $T=T$-Statistics; $P=p$-Value $;$ VAF $=$ Variance Accounted For 
membagi nilai koefisien efek langsung dengan nilai koefensien efek total atau $V A F=\left(p_{12} \cdot p_{23}\right) /\left(p_{12} \cdot p_{23}+\right.$ $\left.p_{13}\right)$. Jika nilai $V A F$ kurang dari $20 \%$ berarti (hampir) tidak ada peran mediasi. Sebaliknya, ketika $V A F$ memiliki hasil yang sangat besar atau di atas $80 \%$ dapat disimpulkan bahwa terdapat peran mediasi penuh (full mediation). Pada situasi VAF lebih besar dari $20 \%$ dan kurang dari $80 \%$ berarti terdapat partial mediation (Hair et al., 2014: 225). Tabel 4 menunjukkan bahwa nilai koefisien indirect effect variabel store atmosphere terhadap kepuasan adalah 0,197 dan signifikan pada $p=0,000$, nilai koefisien indirect effect variabel brand experience terhadap brand satisfaction sebesar 0,429 , signifikan pada $p=$ 0,000 , dan $V A F$ sebesar 34,6\%; dan, nilai koefisien indirect effect variabel brand image terhadap brand loyalty sebesar 0,433 , signifikan pada $p=0,000$, dan VAF sebesar 24,4\%. Dengan nilai $V A F 70,39 \%$ dan $32,78 \%$ maka dapat disimpulkan bahwa pengaruh brand experience terhadap brand satisfaction dimediasi secaca parsial oleh brand image, dan pengaruh brand image terhadap brand loyalty dimediasi secaca parsial oleh brand satisfaction.

\section{PEMBAHASAN}

Tujuan penelitian ini adalah menguji kembali hubungan antar variabel dengan pola "brand experience $\rightarrow$ brand image $\rightarrow$ brand satisfaction $\rightarrow$ brand loyalty". Hubungan antar variabel tersebut diuji melalui enam hipotesis. Hipotesis pertama, yaitu Brand experience berpengaruh langsung secara positif dan signifikan terhadap brand image pengguna smartphone di Tarakan didukung data dan diterima. Temuan ini merupakan bukti empiris yang mendukung model penelitian yang kembangkan oleh Cronin et al. (2000) yaitu, konsep-konsep dari komponen kognitif dapat saling mempengaruhi.

Hubungan brand experience dengan brand satisfaction yang dirumuskan dalamhipotesis kedua, yaitu brand experience berpengaruh langsung secara positif dan signifikan terhadap brand satisfaction pengguna smartphone di Tarakan, tidak terbukti dan ditolak. Dengan demikian, hasil penelitian ini kontradiktif dengan hasil penelitian Sahin et al., (2011) dan Moreira et al. (2017). Temuan studi ini juga mengungkapkan bahwa brand image berperan secara parsial dalam memediasi pengaruh brand experience terhadap terhadap brand satisfaction pengguna smartphone di Tarakan.

Pengaruh brand experience terhadap brand loyalty yang dirumuskan dalam hipotesis ketiga, yaitu brand experience berpengaruh langsung secara positif dan signifikan terhadap brand loyalty pengguna smartphone di Tarakan tidak didukung data dan ditolak. Dengan demikian, temuan penelitian ini kontradiktif dengan hasil penelitian Sahin et al. (2011) dan Nagar dan Bendary (2017) yang mengungkapkan bahwa semakin tinggi tingkat brand experience maka semakin tinggi juga brand loyalty.

Hipotesis keempat, yaitu brand image berpengaruh langsung secara positif dan signifikan terhadap brand satisfaction pengguna smartphone di Tarakan, terbukti dan diterima. Hasil penelitian ini sejalan dengan temuan Dunuwille \& Pathmini, 2016, yang menemukan bahwa semakin tinggi brand imagemaka semakin tinggi brand satisfaction pengguna smartphone.

Hipotesis kelima, yaitu brand image berpengaruh langsung secara positif dan signifikan terhadap brand loyalty pengguna smartphone di Tarakan, didukung data dan diterima. Temuan ini sejalan dengan hasil penelitian empiris yang dilakukan Durrani et al. (2015), dan Mehmood dan Shafiq (2015). Hasil penelitian ini juga mengungkapkan bahwa pengaruh brand image terhadap brand loyalty pengguna smartphone di Tarakan dimediasi oleh brand satisfactiom secara parsial.

Hipotesis keenam, yaitu brand satisfaction berpengaruh langsung secara positif dan signifikan terhadap brand loyalty pengguna smartphone di Tarakan. Temuan ini merupakan salah bukti empiris yang mendukung hasil penelitian Sahin et al. (2011), Kassim et al., (2014), Mehmood dan Shafiq (2015), Pourdehghan, (2015), Goh (2016), Dunuwille dan Pathmini (2016), Fazal dan Kanwal (2017), dan Moreira et al. (2017), yaitu semakin tinggi tingkat brand satisfaction maka semakin tinggi tingkat brand loyalty pengguna smartphone.

\section{KESIMPULAN}

Pola model loyalitas pengguna smartphone berdasarkan temuan penelitian ini adalah: "brand experience $\rightarrow$ brand image $\rightarrow$ brand satisfaction $\rightarrow$ brand loyalty". Secara teoritis, temuan penelitian ini dapat dikategorikan ke dalam aliran kognitif dari teori perilaku konsumen yang mengaplikasikan FourStage Loyalty Model (Oliver, 1997).

Untuk menghadapi persaingan yang semakin kompetitif, manajer pemasaran smartphone harus mampu menciptakan brand experience bagi pelanggannya. Semakin baik brand experience yang diberikan penyedia smartphone, maka semakin tinggi image pengguna terhadap merek smartphone. Brand image yang tinggi akan mempengaruhi kepuasan merek, dan pelanggan yang puas akan loyal terhadap merek smartphone yang sama di masa yang akan 
datang. Dengan demikian, semakin banyak pengguna yang loyal terhadap suatu merek smartphone tertentu akan menjadikan perusahaan pemilik merek smartphone tersebut lebih mudah untuk menguasai pasar, karena pelanggan yang loyal akan membeli dan menggunakan smartphone dengan merek yang sama di masa yang akan datang, serta merekomendasikan dan mengatakan hal-hal positif tentang merek smartphone yang ia gunakan kepada teman dan keluarganya.

\section{DAFTAR PUSTAKA}

Aaker, D. (1991). Managing Brand Equity: Capitalizing on The Value of a Brand Name. New York: Free Press.

Ahmed, S. \& Moosavi, Z. (2013). Factors Influencing the Cell Phone Brand Loyalty of Swedish Generation Y. Master Thesis, Mälardalen University.

Brakus, J., Schmitt, B., H. \& Zarantonello, L. (2009). Brand experience: What is it? Who is it measure? Does it affect loyalty? Journal of Marketing, 73(2009), 52-68.

Chin, W.W., Marcolin, B.L., and Newsted, P.R. (2003). A partial least squares latent vari-able modelling approach for measuring interaction effects: results from a MonteCarlo simulation study and an electronic mail adoption study. Information Systems Research, 14 (2): 189-217.

Cronin, J.J.Jr., Brady, M.K \&Hult, G.T.M. (2000). Assessing the Effects of Quality, Value, and Customer Satisfaction on Consumer Behavioral Intentions in Service Environments.Journal of Retailing.76(2), 193-218.

Dunuwille, V.M. \& Pathmini, M.G.S. (2016). Brand Image and Customer Satisfaction in Mobile Phone Market: Study Based on Customers in Kandy District. Journal of Business Studies, 3(1), 1-13.

Durrani, B.A, Godil, D.I, Baig, M.U., \& Sajid, S (2015). Impact of Brand Image on Buying Behaviour among Teenagers. European Scientific Journal, 11(5), 155-168.

Fazal, O. \& Kanwal, S. (2017). Determinants of brand loyalty: A case study of Asian Mobile Phone Users. International Journal of Scientific and Research Publications, 7(12), 181-191.

Goh, S.K., Jiang, N. \& Tee, P.L. (2016). The Impact of Brand trust, Self-image Congruence and Usage Satisfaction toward Smartphone Repurchase Intention. International Review of Management and Marketing, 6(3), 436-441.

Hair, J.F.Jr., G. Tomas M. Hult, G.T.M., Ringle, C.M., and Sarstedt, M. (2014). A Premier Par- tial Least Squares Structural Equation Modelling (PLS-SEM). Thousand Oaks, California: Sage Publications, Inc.

Hong-Youl Ha \& Joby John (2010) Role of customer orientation in an integrative model of brand loyalty in services. The Service Industries Journal, 30(7), 10251046, DOI: 10.1080/026420608 02311252

Ismail, A.R. (2010). Investigating British customers' experience to maximize brand loyalty within the context of tourism in Egypt: Netnography \& structural modelling approach. PhD Dissertation, Brunel University.

Kassim, A.W.M, Igau, O.A., Harun, A., \& Tahajuddin, S. (2014). Mediating Effect of Customer Satisfaction on Perceived Product Quality, Perceived Value, and Their Relation to Brand Loyalty. International Journal of Research in Management \& Business Studies, 1(2), 13-18.

Keller, K. L. (2001). Building customer-based brand equity: a blueprint for creating strong brands. Marketing Science Institution, Report NO. 01107.

Keller, K.L. (1993) Conceptualizing, Measuring and Managing Customer-based Brand Equity. Journal of Marketing, 57(1), 1-22. http://www.jstor. org/stable/1252054

Kleijnen, M., de Ruyter, K., and Wetzels, M. (2007). An Assessment of Value Creation in Mobile Service Delivery and The Moderating Role of Time Consciousness. Journal of Retailing. 83(1): 33-46.

Kotler, P. and Keller, K.L. (2016). Marketing Management, (15 ${ }^{\text {th }}$ ed.). Edinburgh Gate, Harlow, Essex CM20 2 JE, England: Pearson Education Limited.

Lovelock, C \& Wirtz, J. (2011). Services Matrketing: People, Technology, Strategy, Seventh Edition, New Jersey: Pearson Education, Inc.

Mehmood, W. \& Shafiq, O. (2015). Impact of Customer Satisfaction, Service Quality, Brand Image on Purchase Intention. Journal of Marketing and Consumer Research, 15(2015), 174 186.

Moreira, A.C., Freitas da Silva, P.M., \& Moutinho, V.M.F. (2017). The Effects of Brand Experiences on Quality, Satisfaction and Loyalty: An Empirical Study in the Telecommunications Multiple-play Service Market. INNOVAR. Revista de Ciencias Administrativas y Sociales, 27 (64), 26-36.

Naggar, R.A.A.E. \& Bendary, N. (2017). The Impact of Experience and Brand trust on Brand Loyalty, While Considering the Mediating effect of brand 
Equity Dimension, an Empirical Study on Mobile Operator Subscribers in Egypt. The Business and Management Review, 9(2), 16-25.

Oliver, R.L. (1997). Satisfaction: A Behavioral Perspective on The Consumer (1st ed.). New York: McGraw-Hill Companies.

Pertiwi, W.K. (2018). 2018, Pasar Smartphone Indonesia Tumbuh Dua Digit". https://tekno.kompas. com/read/2019/03/01/16160037/2018-pasarsmartphone-indonesia-tumbuh-dua-digit? page $=$ all. (diakses 01/03/2019).

Pine, D.J. \& Gilmore, J.H. (1998). Welcome to The Experience Economy. Harvard Business Review, July-August 1998, 97 - 105.

Pourdehghan, A. (2015). The impact of marketing mix elements on brand loyalty: A case study of mobile phone industry. Marketing and Branding Research, 2(2015), 44-63.

Prasetya, D.H. (2019). 60+ Merk Logo Handphone Terlengkap.https://www.bitebrands.co/2015/10/ merk-logo-smartphone-terlengkap.html. (diakses 10/08/2019).
Rayana, U. (2019). Siapa Sesungguhnya Penguasa Pasar Smartphone Indonesia? https://selular.id/ 2019/03/siapa-sesungguhnya-penguasa-pasarsmartphone-indonesia/ (diakses 14/03/2019).

Ringle, C. M., Wende, S., \& Becker, J.M. (2015). "SmartPLS 3." Oenningstedt: SmartPLS GmbH. http://www.smartpls.com

Sahin, A., Zehir, C., \& Kitapci, H. (2011). The Effects of Brand Experiences, Trust and Satisfaction on Building Brand Loyalty: An Empirical Research on Global Brands. Procedia Social and Behavioral Sciences, 24(2011), 1288-1301.

Schmitt, B. (1999). Experiential Marketing. Journal of Marketing Management,15(1-3), 53-67. DOI: 10.1362/026725799784870496

Tenenhaus, M., Vincenzo, E.V., Chatelin, Y.M., \& Lauro, C. (2005). PLS path modeling. Сотриtational Statistics and Data Analysis. 48(1): 159-205.

Youl, H. \& John, J. (2010). Role of customer orientation in an integrative model of brand loyalty in services. The Service Industries Journal,30(7), 1025-1046. 